\title{
Development of Lower Limb Muscle Strength Measurement Equipment
}

\author{
by
}

\author{
Noriyuki HISAMORI*
}

When we walk, the quadriceps muscle and hamstring are active. The quadriceps muscle is the muscles that extend the knee and the hamstring is the muscles that bend the knee. The muscle weakness of these muscles causes falls and knee pain. Measuring instruments that measure these muscle strengths are used in clinical practice. However, since it does not take into consideration the position of muscle and bone attachment, it cannot be measured under conditions that maximize muscle strength. The purpose of this study is to develop a muscle strength measuring device of the quadriceps femoris and hamstring under conditions that maximize muscle strength taking into consideration the position of muscle and bone attachment. In this study, muscular strength was measured for 7 men in their 20s and 7 females in their 20s. As a result, we could measure muscular strength of the quadriceps femoris and hamstring under conditions that maximize muscle strength. However, the measurement results of subjects with long thigh tended to decrease. This result may be due to the lack of fixation of the knee if the subject is a long thigh. Therefore, to measure muscle strength accurately, it was suggested that it is necessary to design a measurement instrument that takes the subject's thigh length into account.

Key words: Quadriceps femoris, Hamstring, Muscle strength, Hip joint angle, Knee joint angle, Thigh length

\section{1 緒言}

近年, 健康寿命の延伸が求められている.なかでも，骨 や筋肉, 靭帯などの運動機能の維持が重要とされている. 例えば, 歩行時に重要な下肢の筋肉は, 太もも前面部の大 腿四頭筋と背面部のハムストリングである．前者の筋肉 は膝を伸ばす動作を, 後者は曲げる動作を担っている.こ れらの筋力が低下すると転倒, 骨折, 変形性膝関節症など を誘発し，寝たきりの症例に繋がるとされている.

下肢筋肉の診療には, 例えば, ハンドヘルドダイナモメ ーターなどの簡易型の機器が使用されている 1) (Fig. 1). 高齢者のわずかな筋力でも数值化できることから, リ八 ビリの進捗状況を知ることができる.この機器は, 検者が 機器を被験者の足根骨部に当て, 被験者が機器に力を加 えることで筋力を測定している.したがって, 検者の機器 の持ち方, 足根骨部への当て方や位置などで筋力值は変 化するため, 注意が必要である ${ }^{2), 3) . ~}$

大腿四頭筋とハムストリングは，股関節と膝関節に付 着している二関節筋である. 寸なわち, 各関節角度で発揮 される筋力量は異なることが知られている ${ }^{4)}$. 上述の機器 を用いた大腿四頭筋の測定は座位で行い，ハムストリン グの測定は腹臥位で行う。このことは, 関節角度を考慮し た測定, 言い換えれば, 毎回同じ関節角度で測定しないと 継続的な筋肉量の評価・診断が行えないことを意味して いる. 加えて, 最大筋力值や再現性に曖昧さを有している.
一方，大学病院などの整形外科学分野や，スポーツ医 学分野では, 筋力を計測する高級な機器として多用途筋 機能評価運動装置バイオデックスシステム（Biodex）が 導入されている (Fig. 2) 5). 本装置は，抵抗を受けるア 一ムの中心にモーターとトルクを感知するセンサーが内 蔵されており, 結果はモーメント（トルク）で表示され る. 加えて, 様々な速度で測定を行うことで日常生活動 作に近い筋力を評価できる，スポーツ界を含む世界中の 幅広い対象者に利用されている. とくに, 個人の筋力特 性に応じた測定メニューが多く，下肢のみならず上肢の 評価も行うことができる，そして，二関節筋を考慮して おり, 足を固定する位置が変わっても結果に影響せず, 再現性の高い測定ができる，しかしながら，高価である ことや，持ち運びはできないことが難点である.

その他，様々な筋力を測定する機器が販売されている が, 大腿四頭筋を測定する機器が多く, 同一機器でハムス トリングも測定できる製品は少ないようである. 加えて, 二関節筋を考慮した機器も少なく, 得られる結果をどの ように評価し，診断するか課題を有している.

著者らは，歩行運動を支える下肢筋肉の大腿四頭筋と ハムストリングの股関節と膝関節間の解剖学的骨付着位 置を考慮し, 最大限の筋力が発揮する関節角度下で筋力 測定可能な測定器の開発を行った. 本解説では, 開発した 下肢筋力測定器から得れる結果について, 評価および診 断についての考え方を解説する.

$\dagger$ 原稿受理 31年 3月 15日 Received Mar. 15, 2019 @2019 The Society of Materials Science, Japan

* 正会員 上智大学 理工学部 機能創造理工学科 $\bar{\top} 102-85445$ 東京都千代田区

Faculty of Science and Technology, Department of Engineering and Applied Sciences, Sophia University, Chiyoda-ku, Tokyo 102-8554. 


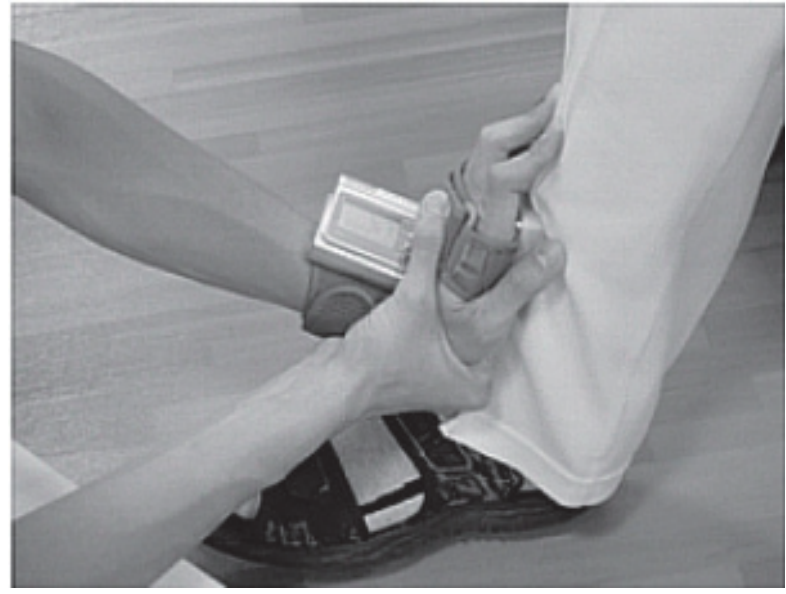

Fig. 1 Hand-held dynamometer.

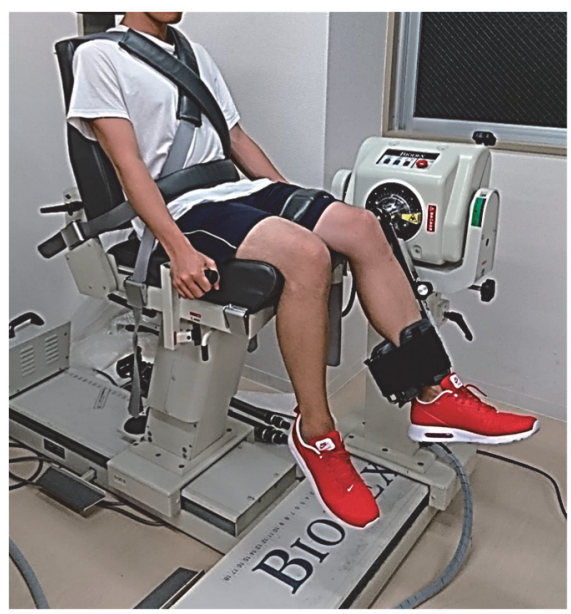

Fig.2 Measurement using Biodex.

\section{2 開発した下肢筋力測定器の概要}

下肢の筋肉のうち歩行などへの影響が大きい筋肉は， 大腿四頭筋と八ムストリングである. しかしながら, 前述 したとおり, 現状の下肢筋力測定器は大腿, 膝下および足 首を含んだ脚全体の筋力を測定するものが多い. 加えて, 解剖学的な筋肉の付着位置を考慮した測定器は少ない.

したがって，股関節および膝関節に跨って繋がっている 二関節筋を考慮した測定器の開発を目指した. 加えて, 持 ち運びが可能であることも目指した，そのためには，毎回 の測定において，股関節および膝関節の角度を同程度の 位置に合わせることができる機器を開発する必要がある.

Fig. 3 に開発した下肢筋力測定器の外観を示す. 本測定 器は, 汎用されているトレーニングマシン (ALINCO 社製 マルチアームジム G3100) を改良したものである. マシン のベンチ部は，人の背骨ラインにフィットする背もたれ が付いている. 加えて, 背もたれ角度を調整することで股 関節角度を保持できる. 一般に, 股関節の内圧が最も低く なる角度は $60^{\circ}$ であることが知られている ${ }^{6)}$.このことは, 寛骨から大腿骨に付着する腸骨大腿靭帯，坐骨大腿靭帯， 恥骨大腿靭帯が弛緩するためである。すなわち, 最も関節 痛を感じにくい角度であることを意味している。これよ り，現状の股関節固定角度は $60^{\circ}$ としている。ベンチ部の
シートの長さは， $42 \mathrm{~cm}$ から $54 \mathrm{~cm}$ まで $3 \mathrm{~cm}$ の可変式であ り，被験者の大腿の長さに調整できる.

膝パットからアームを介してレッグパットが取り付け られている.アームを固定することで, 膝関節角度を保持 できる.アームの長さは， $30 \mathrm{~cm}$ から $48 \mathrm{~cm}$ まで $3 \mathrm{~cm}$ の可 変式であり，被験者の下肢の長さにアームの長さを調整 できる.

大腿部前面に位置する大腿四頭筋は, 筋肉群の総称で ある. なかでも, 膝関節の伸展と股関節の屈曲を担う大腿 直筋は, 腸骨から脛骨に付着している二関節筋である。一 般に, 大腿四頭筋は膝関節 $60^{\circ}$ において最大筋力を発揮す ることが知られている ${ }^{4)}$ 。このことは, 大腿四頭筋の脛骨 への付着位置と, 膝関節の回転軸との距離が最大になる ためである ${ }^{6}$.

大腿部背面に位置するハムストリングは，膝関節の屈 曲と股関節の伸展を担う筋肉群の総称である. 大腿二頭 筋は坐骨から腓骨, 半膜様筋は坐骨から大腿骨と脛骨, 半 腱様筋は坐骨から脛骨に付着している二関節筋であり, 膝関節の屈曲と股関節の伸展を担っている。一般に, 八ム ストリングは膝関節 $45^{\circ}$ において最大筋力を発揮するこ とが知られている ${ }^{4)}$.このことは，八ムストリングの筋長 が伸びることで発揮する筋力が最大になるためである ${ }^{6}$. 以上より, 開発した下肢筋力測定器は, 股関節角度と膝関 節角度を固定することで，常に同じ関節角度で測定を行 うことができる. すなわち, 解剖学的な二関節筋を考慮し

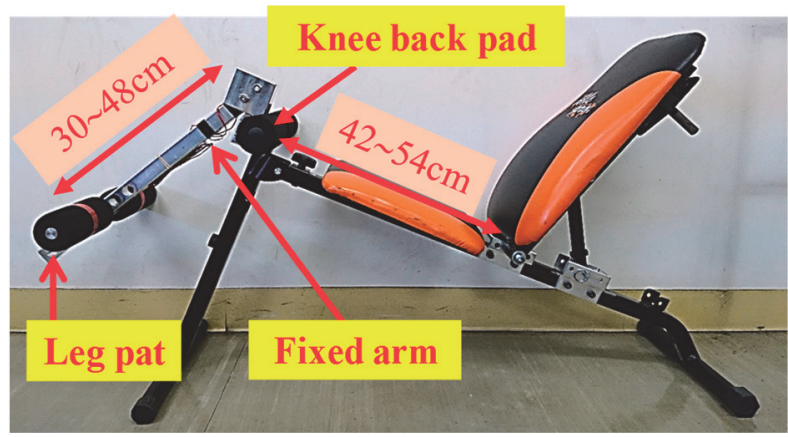

(a) Configuration of measuring equipment

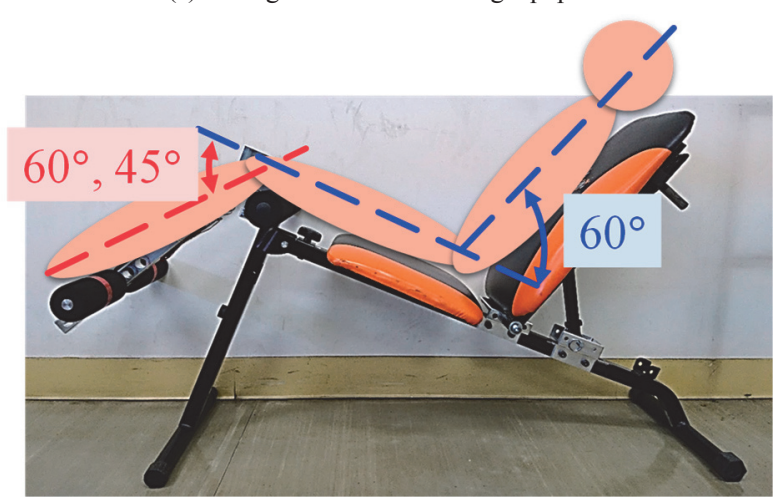

(b) Femoral angle $\left(60^{\circ}\right)$ and knee angle (Quadriceps femoris; $60^{\circ}$, Hamstring; $45^{\circ}$ )

Fig. 3 Appearance of lower limb muscle strength measuring device considering bipartite muscle. 
た大腿四頭筋とハムストリングの筋力測定を可能とする 機器である.

\section{3 開発した下肢筋力の測定方法}

筋力測定には，ひずみゲージを使用した。ひずみゲージ をアームの回転中心から $10 \mathrm{~cm}$ の位置に貼り（Fig. 4）、レ ッグパットに力を加えた際にアームに発生する曲げひず みから荷重を算出し，これを筋力值と定義した。膝関節の 伸展と屈曲を行うことで大腿四頭筋とハムストリングの 筋力を測定する本測定器においては, 膝窩（膝裏）と膝パ ットとの位置が一致していることが最も重要である。し たがって, 被験者には背もたれに沿って深く腰掛け, 膝窩 を膝パットの上に合わせた姿勢でレッグパットに足根骨 部を当てて筋力の測定を行った。つまり, 大腿四頭筋の測 定は, レッグパットの下に足関節前面を当て, 膝を伸ばす 力を加える (Fig. 5(a)). 八ムストリングの測定は，レッグ パットの上に足関節後面をのせ, 膝を曲げる力を加える

(Fig. 5(b)) .このように本測定器は, 膝パットを支点とし てレッグパットを介して膝を伸展・屈曲動作を加えるこ とで筋力を測定した. そのため, 被験者の足根骨部はレッ グパットの位置に合うようにレッグアーム長さを調節し た. 実際に力を加える際には, レッグアームは固定されて おり，被験者は固定したレッグパットに足根骨部で力を 加えて, 大腿四頭筋 (伸展) および八ムストリング (屈曲) の筋力を測定した。したがって, 脛骨下端（脛骨遠位）は 動かないものと考えている.また, 体幹を固定するために, 腹部と大腿近位を幅広ベルトで固定した. なお, 八ムスト リングの測定は, 力を加えたときに膝が浮くことから, 大 腿骨遠位も幅広ベルトで固定した。

下肢筋力の測定は，股関節に整形外科的疾患既往のな い健常学生 20 代男性 7 人（7 脚） と女性 7 人（7脚）で実 施した. なお, ボールを蹴る側を対象脚とした. Table 1 に 被験者の年齢, 身長, 体重の平均值, 最大值, 最小值を示 す. 筋力を発揮する時間, 寸なわち, 力を加える時間は 5

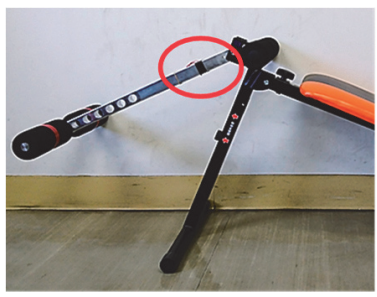

(a)

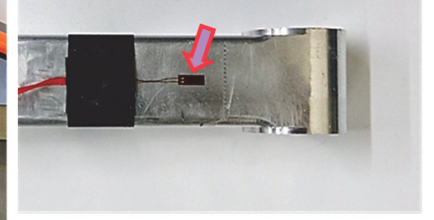

(b)
Fig. 4 Measurement of strain. (a) The arm of dynamometer, (b) Strain gauge.

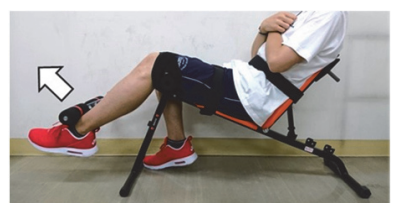

(a)

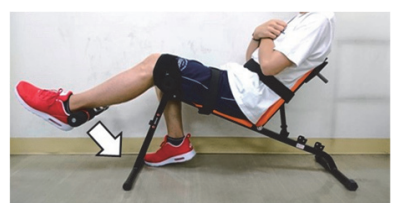

(b)
Fig. 5 Leg strength measurement. (a) Quadriceps femoris strength measurement (b) Hamstring strength measurement.
秒間保持とした. そして, 30 秒のインターバルを設け, 計 3 回実施し, その最大值を筋力值とした.

Table 1 Physical feature of subjects.

\begin{tabular}{|c|c|c|c|c|}
\hline & \multicolumn{2}{|c|}{ Men } & \multicolumn{2}{c|}{ Women } \\
\hline Age & \multicolumn{2}{|c|}{22.4} & \multicolumn{2}{c|}{22.7} \\
\hline $\begin{array}{c}\text { Height } \\
{[\mathrm{cm}]}\end{array}$ & \multirow{2}{*}{172.6} & +9.4 & \multirow{2}{*}{157.1} & +4.9 \\
\cline { 3 - 3 } Weight $[\mathrm{kg}]$ & \multirow{2}{*}{59.1} & -9.6 & & -4.1 \\
\cline { 3 - 3 } & & -12.4 & \multirow{2}{*}{46.7} & +3.3 \\
\cline { 5 - 5 } & & &
\end{tabular}

\section{4 開発した下肢筋力測定器による測定結果と検証}

\section{1 男性 7 人における下肢筋力の測定結果}

Table 2 に男性被験者 7 人の大腿長さに対する大腿四頭 筋およびハムストリングの筋力值（kgf）を, 被験者の体 重 $(\mathrm{kg})$ で割った体重比を示す. 体重比で整理することで, 被験者の体格に左右されない数值として比較できる. 得 られる筋力值が正しく測定できていることを検証するた めに, シート長さを $45 \mathrm{~cm}$ とした結果である. すなわち, 股関節角度を $60^{\circ}$ に固定する本測定では, 被験者がシート の背もたれに沿って深く腰掛けた結果, シート長さ $(45 \mathrm{~cm})$ よりも大腿が長い被験者は, 膝窩と膝パットの位置は一 致しない姿勢となる（Fig.6(a)）。つまり，膝窩あるいは大 腿遠位は, 膝パットを通り越した位置にある. 同様に, シ 一ト長さ $(45 \mathrm{~cm})$ よりも大腿が短い被験者は, 背もたれに 沿って深く腰掛けて座ると, 膝窩が膝パットに届かない 姿勢となる.このような被験者には, 座った後に膝窩を膝 パットの位置に合わせるように指示した (Fig. 6(b)). すな わち，膝窩あるいは脛骨近位は膝パットと一致している が，臀部と背もたれに隙間がある姿勢で膝パットに力を 加えて筋力を測定した.

Table 2 より, 大腿が測定器のシート長さ $(45 \mathrm{~cm})$ と同 じ被験者 7 における大腿四頭筋およびハムストリングの 体重比は, 大腿が測定器のシート長さよりも長い被験者 （被験者 1～6）より大きいことがわかる.このことは, 被験者 7 の膝窩と膝パットの位置が一致しているためで ある. 言い換えれば, 膝窩と膝パットの位置が一致してい ない被験者 $1 \sim 6$ の測定結果は, 最大の筋力が発揮されて いないと考えられる. 本測定器で得られる筋力は, 股関節 角度と膝関節角度を固定した状態, 寸なわち, 関節運動を 伴わない状態で発揮される等尺性筋力を評価している. すなわち，筋肉の長さが変わらない状態で力を発揮する 等尺性収縮下の筋力測定を行っている.つまり, 筋力と負 荷が釣り合っている状態を意味している。一般に, 最大の 等尺性筋力を発揮させるためには，筋肉の両端を固定す る必要があると報告されている6)。すなわち, 関節角度を 固定した動かないものに対して力を加えることで, 限定 した筋力のみを測定できる.したがって, 脛骨近位に付着 している大腿四頭筋およびハムストリングは, 膝窩と膝 パットの位置, すなわち, 脛骨近位を固定することで最大 の筋力が発揮できることを意味している.これより, 膝窩 
Table 2 Result of leg strength measurement ( 7 men); sheet length $45 \mathrm{~cm}$

\begin{tabular}{|c|c|c|c|}
\hline Subjects & $\begin{array}{c}\text { Thigh length } \\
{[\mathrm{cm}]}\end{array}$ & $\begin{array}{c}\text { Quadriceps femoris } \\
{[\%]}\end{array}$ & $\begin{array}{c}\text { Hamstring } \\
{[\%]}\end{array}$ \\
\hline 1 & 53 & 84.1 & 39.1 \\
\hline 2 & 52 & 80.5 & 42.1 \\
\hline 3 & 51 & 126.0 & 68.0 \\
\hline 4 & 50 & 82.1 & 45.2 \\
\hline 5 & 49 & 85.6 & 50.1 \\
\hline 6 & 48 & 98.2 & 50.2 \\
\hline 7 & 45 & 112.6 & 63.8 \\
\hline
\end{tabular}

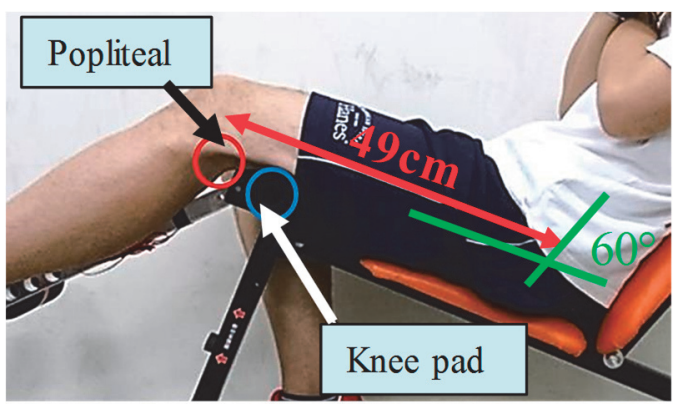

(a) Subjects with long thigh

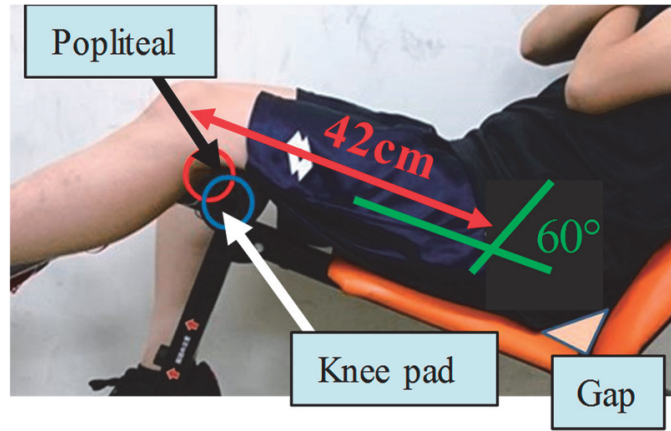

(b) Subjects with short thigh

Fig. 6 Position of the knee and knee pads. (Sheet length $=45 \mathrm{~cm}$ ).

と膝パットの位置が一致していない被験者は，伸張性収 縮や短縮性収縮のように筋肉が伸び縮みしながら発揮さ れた筋力を測定している。つまり，筋力と負荷が釣り合っ ていない状態である. 以上より, 膝窩と膝パットの位置が 一致していること，且つ，レッグパットと足根骨部（脛骨 遠位) が固定されていることが重要である。したがって, 測定器のシート長さを調整する, すなわち, 膝窩と膝パッ トの位置が一致した姿勢で筋力測定を行うことが重要で ある.そこで, Fig.7 に示すような背もたれ位置を変更し， 各被験者の大腿長さと測定器のシート長さを調整するこ とで膝パットと膝窩位置をできるだけ一致させた姿勢で 筋力測定を行った. その結果を Table 3 に示す. 同表より, 測定器のシート長さと大腿長さを合わせることができた 被験者（被験者 3,6，(7)）では，大きな筋力值が得られて いることがわかる，これより，膝パットと膝窩位置をでき るだけ一致させることで，最大の筋力を発揮することが 示唆された. すなわち, 脛骨近位に付着している大腿四頭 筋および八ムストリングの測定には，二関節筋という解

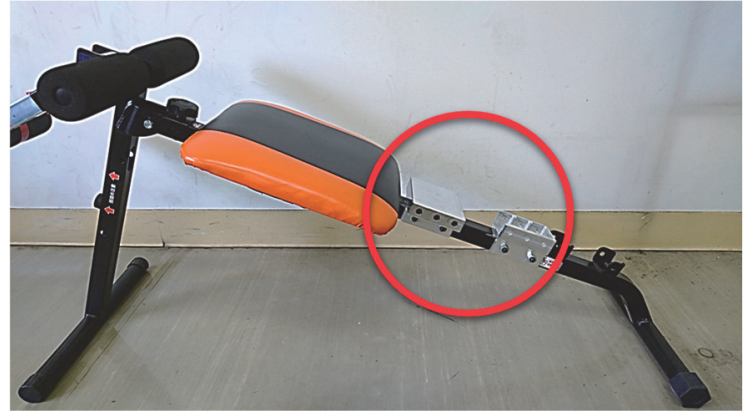

Fig. 7 Moving mechanism of the backrest.

Table 3 Result of leg strength measurement (7 men).

\begin{tabular}{|c|c|c|c|c|}
\hline Subjects & $\begin{array}{c}\text { Thigh length } \\
{[\mathrm{cm}]}\end{array}$ & $\begin{array}{c}\text { Sheet length } \\
{[\mathrm{cm}]}\end{array}$ & $\begin{array}{c}\text { Quadriceps } \\
\text { femoris } \\
{[\%]}\end{array}$ & $\begin{array}{c}\text { Hamstring } \\
{[\%]}\end{array}$ \\
\hline 1 & 53 & 51 & 91.9 & 35.8 \\
\hline 2 & 52 & 51 & 103.5 & 52.4 \\
\hline 3 & 51 & 51 & 136.6 & 78.5 \\
\hline 4 & 50 & 51 & 100.0 & 50.6 \\
\hline 5 & 49 & 48 & 108.0 & 55.5 \\
\hline 6 & 48 & 48 & 108.0 & 57.9 \\
\hline 7 & 45 & 45 & 107.0 & 60.5 \\
\hline
\end{tabular}

剖学的特徵を測定器に反映させることが重要である。し かしながら，最大筋力を発揮する股関節角度と膝関節角 度との関係については，今後の調査が必要である。

\section{2 女性 7 人における下肢筋力の測定結果}

Table 4 に女性被験者 7 人の大腿長さに対する大腿四頭筋 および八ムストリングの竻力值 $(\mathrm{kgf})$ を, 被験者の体重 (kg) で割った体重比を示す. 大腿が $45 \mathrm{~cm}$ 以下の被験者 は, 膝パットと脛骨近位部は一致しているが, 臂部と背も たれとには隙間がある姿勢での測定結果である。同表よ り，大腿が測定器のシート長さ $(45 \mathrm{~cm})$ よりも長い被検者 1 の大腿四頭筋および八ムストリングの体重比は, 他の被 験者に比べて小さいことがわかる。すなわち，膝パットと 膝窩の位置をできるだけ一致させることが重要である. 加えて，臀部と背もたれに隙間がある被験者 5 と 6 にお いては，大きな大腿四頭筋およびハムストリングの体重 比が得られており, 膝窩と膝パットの一致は重要である ことを示唆している. しかしながら, 隙間がある状態で測

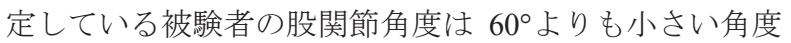
で力を加えている。一般に, 股関節角度によって大腿直筋

Table 4 Result of leg strength measurement (7 women).

\begin{tabular}{|c|c|c|c|}
\hline Subjects & $\begin{array}{c}\text { Thigh length } \\
{[\mathrm{cm}]}\end{array}$ & $\begin{array}{c}\text { Quadriceps femoris } \\
{[\%]}\end{array}$ & $\begin{array}{c}\text { Hamstring } \\
{[\%]}\end{array}$ \\
\hline 1 & 46 & 78.2 & 37.4 \\
\hline 2 & 45 & 102.5 & 49.1 \\
\hline 3 & 45 & 83.8 & 34.1 \\
\hline 4 & 44 & 96.9 & 60.5 \\
\hline 5 & 42 & 116.6 & 51.8 \\
\hline 6 & 42 & 145.6 & 53.8 \\
\hline 7 & 41 & 75.9 & 46.3 \\
\hline
\end{tabular}


とハムストリングの筋長が変化するため ${ }^{6}$, 最大の筋力は 発揮されていないと考えられる. したがって, 股関節角度 が筋力に与える影響については, 今後の検証課題である.

\section{3 開発した下肢筋力測定器と Biodex との比較}

開発した測定器が最大筋力を測定できていることを検 証するため, Biodex を用いて同様の下肢筋力測定を行っ た. 但し, Biodex の構造上, Biodex での股関節角度は $80^{\circ}$ とした。被験者は Table 2 の被験者 6 とした。なお, 1 日 目にBiodex，翌日に開発した本測定器で測定した. Table 5 に大腿四頭筋およびハムストリングの筋力值 $(\mathrm{kgf})$ を示 す. 同表より，開発した筋力測定器と Biodex で得られた 大腿四頭筋の筋力值の差異は，右足で $1.6 \mathrm{kgf}(2.9 \%)$, 左 足で $0.22 \mathrm{kgf}(0.54 \%)$ であることがわかる.これに対して ハムストリングの筋力值の差異は, 右足で $5.02 \mathrm{kgf}$ $(15.8 \%)$, 左足で $3.69 \mathrm{kgf}(12.5 \%)$ であり, Biodex の方 が大きいことがわかる. H.Lund らは，同一の被験者で異 なる測定器を用いて同一条件で筋力測定を行った結果, 大腿四頭筋において $12.9 \%$ ， ハムストリングにおいて $16.8 \%$ のばらつきを報告している7)。これより，開発した 筋力測定器と Biodex との筋力值の差異は, 同報告よりも 小さいことから, 妥当な結果と考えている. 寸なわち, 二 関節筋を考慮することで, 現行の Biodex と同程度の筋力 值を得ることが明らかとなった。

Table 5 Result of leg strength measurement.

\begin{tabular}{|c|c|c|c|}
\hline \multirow{2}{*}{ Right leg } & Type & $\begin{array}{c}\text { Quadriceps femoris } \\
{[\mathrm{kgf}]}\end{array}$ & $\begin{array}{c}\text { Hamstring } \\
{[\mathrm{kgf}]}\end{array}$ \\
\cline { 2 - 4 } & Development equipment & 54.89 & 26.61 \\
\hline \multirow{2}{*}{ Left leg } & Biodex & 53.29 & 31.63 \\
\cline { 2 - 4 } & Development equipment & 40.60 & 25.62 \\
\cline { 2 - 4 } & Biodex & 40.80 & 39.31 \\
\hline
\end{tabular}

4. 4 測定回数や継続的に測定した際の筋力値の考え方

開発した測定器を用いて, 同一の被験者を対象に 30 日 間の筋力測定を行った。被験者は Table 2 の被験者 6 とし た. 筋力測定の条件は, 力を加える最大の保持時間を 5 秒 間とし，30 秒のインターバルを設け，計 3 回実施した. 加えて, 1 日以上の間隔を設けて計 30 日行った（3 回× 30 日). 1 日 3 回の測定結果の最大值を $\mathrm{Vmax}$, 平均值を Vave と定義する. Fig. 8 に 3 回 $\times 30$ 日の大腿四頭筋の測 定結果（度数分布）を示寸. 同図より，1 回目の筋力值に 比べて, 2 回目および 3 回目に得られる筋力值は小さいこ とがわかる.このことは, 連続測定に伴う疲労（体力）の 影響が考えられる.一般に, 複数回の筋力測定には, 測定 に慣れることで筋力值が大きくなる学習効果と, 疲れる ことで筋力值が小さくなる疲労効果がある 7 ). これより, 本測定器における測定回数は, 疲労効果が表れる 3 回ま での筋力測定で十分であることがわかる．この傾向は八 ムストリングでも同様である.

Fig. 9 に大腿四頭筋の Vmax の度数分布を示す．同図よ り, Vmax が得られるのは，主に 1 回目と 2 回目の測定で あることがわかる. 加えて, 最大筋力值 $59.92 \mathrm{kgf}$, 最小筋

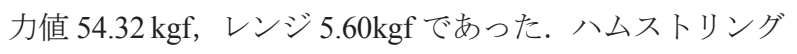
でも同様の傾向を示し, 最大筋力值 $28.51 \mathrm{kgf}$, 最小筋力值

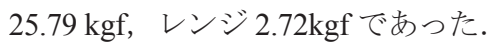

Fig. 10 に大腿四頭筋の Vave の度数分布を示す. 最大筋 力值 $56.41 \mathrm{kgf}$, 最小筋力值 $52.72 \mathrm{kgf}$, レンジ $3.69 \mathrm{kgf}$ であ った. 八ムストリングでも同様の傾向を示し, 最大筋力值 $28.51 \mathrm{kgf}$, 最小筋力值 $25.79 \mathrm{kgf}$, レンジ $2.72 \mathrm{kgf}$ であった。 これらの結果より, 筋力值には最大值 Vmax に加えて最 頻值も存在することがわかる。ここで, Vmax を筋力值と 定義する場合, Fig. 9 より大腿四頭筋の最大筋力值は $59.92 \mathrm{kgf}$ (ハムストリング $28.51 \mathrm{kgf}$ ) であることがわかる. これは, 瞬間の筋力発揮が求められるアスリートなどの 競技力の指標に有用である.しかしながら, 継続的な筋力 測定を行う場合, 最大值の出現率は低く, 再現性に乏しい

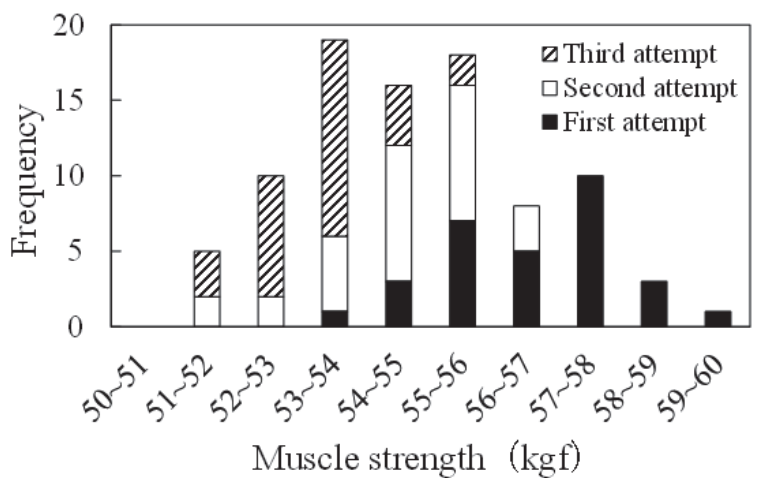

Fig. 8 Frequency distribution of quadriceps femoris measurement $(\mathrm{n}=3$ $\times 30)$.

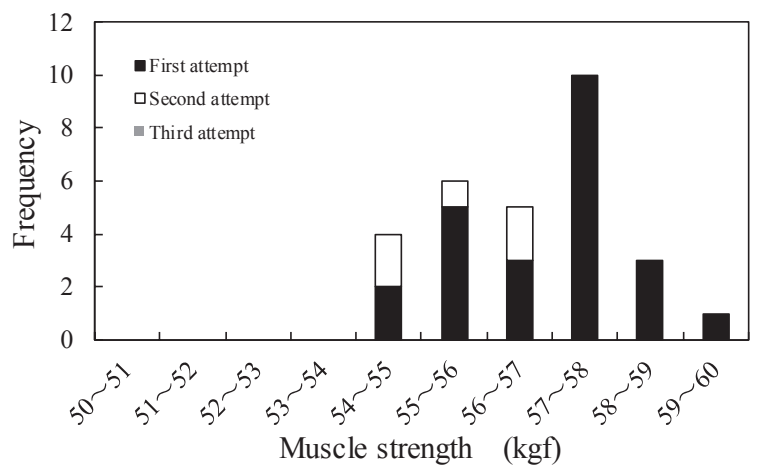

Fig. 9 Frequency distribution of quadriceps femoris measurement (V $\max )$.

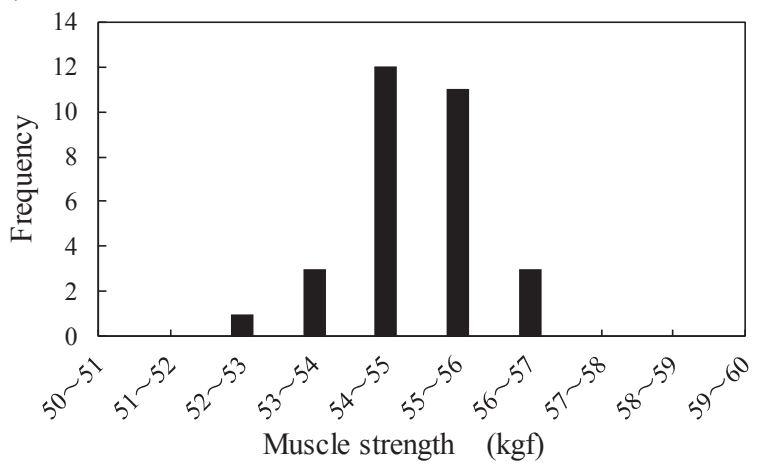

Fig. 10 Frequency distribution of quadriceps femoris measurement (V ave). 
と考えられる。これに対して，一般人を対象とした日常 生活で必要な筋力值は，安定的な再現性の高い数值が得 られる最頻值の採用が望ましいと考える。すなわち, Vaveを採用・提示することを著者らは提案している。そ こで, 開発した測定器を用いて, 複数の被験者を対象に, 10 日間にわたる筋力測定を行った。測定は 20 代男性 6 人 と女性 6 人で実施した。前述と同様の測定条件で，1 日以 上の間隔を設けて 10 回測定した結果の最大值と最小值お よび，最大值と最小值の差を最大值で割ったばらつき $(\%)$ を算出した男性の結果を Table 6 (大腿四頭筋) , Table 7 (八 ムストリング）に示す。これより，大腿四頭筋で最大 $10.26 \%$ ，平均 $7.78 \%$ ，八ムストリングで最大 $15.18 \%$ ，平 均 $11.70 \%$ のばらつきがあることがわかる，すなわち，平 均值 Vave を採用する場合の本測定器の精度を意味してい る.これらの結果は，現行の Biodex と同程度のばらつき であり，妥当な結果と考えている7). したがって，3 回の 筋力測定結果の平均值を筋力值と定義することで，ばら つきの小さい筋力測定を行えることができ，評価や診断 に繋げることが可能である.

Table 6 Maximum and minimum value of quadriceps femoris measurement (6 men).

\begin{tabular}{|c|c|c|c|}
\hline Subjects & $\begin{array}{c}\text { Maximum value } \\
(\%)\end{array}$ & $\begin{array}{c}\text { Minimum value } \\
(\%)\end{array}$ & $\begin{array}{c}\text { Variability } \\
(\%)\end{array}$ \\
\hline 1 & 93.74 & 86.22 & 8.02 \\
\hline 2 & 90.98 & 84.37 & 7.27 \\
\hline 3 & 119.24 & 113.08 & 5.17 \\
\hline 4 & 88.53 & 82.65 & 6.64 \\
\hline 5 & 98.58 & 89.39 & 9.33 \\
\hline 6 & 95.16 & 85.39 & 10.26 \\
\hline
\end{tabular}

Table 7 Maximum and minimum value of hamstring measurement (6 men).

\begin{tabular}{|c|c|c|c|}
\hline Subjects & $\begin{array}{c}\text { Maximum value } \\
(\%)\end{array}$ & $\begin{array}{c}\text { Minimum value } \\
(\%)\end{array}$ & $\begin{array}{c}\text { Variability } \\
(\%)\end{array}$ \\
\hline 1 & 46.12 & 39.12 & 15.18 \\
\hline 2 & 48.29 & 42.9 & 11.17 \\
\hline 3 & 60.19 & 53.41 & 11.27 \\
\hline 4 & 47.98 & 43.62 & 9.08 \\
\hline 5 & 51.6 & 43.98 & 14.77 \\
\hline 6 & 56.87 & 51.9 & 8.75 \\
\hline
\end{tabular}

5 結 言

本解説では，歩行運動を支える下肢筋肉の大腿四頭筋 とハムストリングの股関節と膝関節間の解剖学的骨付着 位置を考慮し，最大限の筋力が発揮する関節角度下で筋 力測定可能な測定器の開発を行った. 筋力測定は, 固定ア 一ム部にひずみゲージを貼り，レッグパットに垂直荷重 を加えた際に発生する曲げひずみから荷重を算出し，筋 力值と定義した。 以下に得られた結果を示す。
1）大腿四頭筋とハムストリングを同一の機器で測定でき るポータブル型（現状 $8 \mathrm{~kg}$ ）筋力測定器を開発した.

2）大腿四頭筋およびハムストリングの解剖学的な骨への 付着位置 (二関節筋) を考慮し，股関節角度と膝関節角度 を常に固定した姿勢で得られた測定結果は，現行の Biodex と同程度である.

3）筋力值の定義として，アスリートなどの競技レベルの 向上を目指寸場合は最大筋力值 V max を採用し，健康維 持を目的とする一般健常者や，リハビリテーションによ る健康回復を目的とする場合は平均筋力值 $\mathrm{V}$ ave を採用 することを提案する.

4）開発した下肢筋力測定機器で得られる大腿四頭筋お よび八ムストリングの筋力值の精度は，前者で $11.61 \%$, 後者で $11.70 \%$ であり，現行の Biodex と同程度であるこ とが検証された。

本研究・開発は, 慶應義塾大学医学部スポーツ医学総 合センター松本秀男教授および東宏一郎講師との共同 で行ったものである。また，筋力測定にご協力頂いた被 験者の皆様に感謝の意を述べる。

1) T. Ikai, "Assessments of muscle strength and muscle volume", Journal of clinical and experimental medicine, Vol.236, No.5, pp.465-469 (2011).

2) Y. Miyazaki, M. Miyazu and T. Kiyama "Absolute reliability of hip extensor strength assessment using a hand-held dynamometer with a belt", Journal of the aichi cociety for physical therapy, Vol.28, No.2, pp.54-60 (2016).

3) M. Kato, H. Yamasaki, K. Nakajima and K. Kaji "Measurements of isometric hip flexion and extension force with a hand-held dynamometer: The effect of use of the belt for fixation on the reliability", Kochi Rehabilitation Institute, Vol.6, pp.7-13 (2005).

4) S. Kotoshiba, Y. Urabe, Y. Maeda, H. Shinohara, J. Sasashiro, Y. Fujii and S. Moriyama, "The influence of differences in trunk solidity and change in hip joint angle to lower extremity muscle activity during quadriceps setting", Journal of Physical Therapy Practice and Research, Vol.22, No.5, pp.21-24 (2013).

5) https://www.sakaimed.co.jp/.

6) D. A. Neumann, "Kinesiology of the musculoskeletal system", Elsevier, Vol.3, pp.569-606 (2018)

7) H.Lund, K.Søndergaard, T.Zachariassen, R.Christensen, P.Bülow, M.Henriksen, E.M.Bartels, B.Danneskiold-samsøe and H.Briddal, "Learning effect of isokinetic measurements in healthy subjects, and reliability and comparability of Biodex and Lido dynamometers", Clin Physiol Funct Imaging, Vol.25, No.2, pp7585 (2005). 